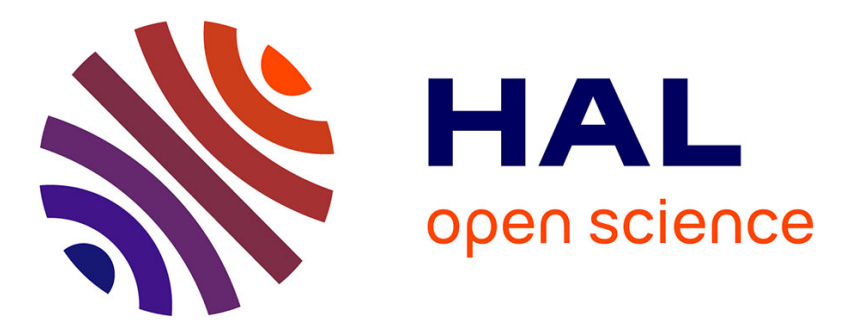

\title{
Fine-scale interactions between boats and large albatrosses indicate variable susceptibility to bycatch risk according to species and populations
}

\author{
A. Corbeau, J. Collet, F. Orgeret, P. Pistorius, H. Weimerskirch
}

\section{To cite this version:}

A. Corbeau, J. Collet, F. Orgeret, P. Pistorius, H. Weimerskirch. Fine-scale interactions between boats and large albatrosses indicate variable susceptibility to bycatch risk according to species and populations. Animal Conservation, 2021, 24 (4), 10.1111/acv.12676 . hal-03138918

\author{
HAL Id: hal-03138918 \\ https://hal.science/hal-03138918
}

Submitted on 28 Oct 2021

HAL is a multi-disciplinary open access archive for the deposit and dissemination of scientific research documents, whether they are published or not. The documents may come from teaching and research institutions in France or abroad, or from public or private research centers.
L'archive ouverte pluridisciplinaire $\mathbf{H A L}$, est destinée au dépôt et à la diffusion de documents scientifiques de niveau recherche, publiés ou non, émanant des établissements d'enseignement et de recherche français ou étrangers, des laboratoires publics ou privés. 


\section{Fine-scale interactions between boats and large albatrosses}

\section{2 indicate variable susceptibility to bycatch risk according to species}

\section{3 and populations}

4

5 Alexandre CORBEAU ${ }^{1 *}$

6 Julien COLLET ${ }^{2}$

7 Florian ORGERET ${ }^{3,4}$

$8 \quad$ Pierre PISTORIUS ${ }^{3,4}$

9 Henri WEIMERSKIRCH ${ }^{1}$

$11{ }^{1}$ Centre d'Études Biologiques de Chizé, UMR7372 CNRS-La Rochelle Université, 79360

12 Villiers en Bois, France.

13 2 University of Oxford, Department of Zoology, Oxford OX1 2JD, United Kingdom.

$14{ }^{3}$ DST/NRF Centre of Excellence at the FitzPatrick Institute for African Ornithology, Department of Zoology, Nelson Mandela University, Port Elizabeth 6031, South Africa.

17 Mandela University, Port Elizabeth 6031, South Africa. 


\section{Abstract}

24 Many seabirds are attracted to fishing boats where they exploit foraging opportunities which

often involve bycatch-related mortality. Bycatch risk is generally estimated by overlapping seabirds foraging ranges with coarse-scale monthly maps of fishing efforts. A more direct estimation would be the time birds spend attending fishing boats.

Here we matched data from Automatic Identification Systems from all declared boats in the Southern Ocean, with 143 simultaneous foraging trips from all populations of large albatrosses (Diomedea amsterdamensis and Diomedea exulans) breeding in the Indian Ocean (Marion, Crozet, Kerguelen, Amsterdam islands). We quantified and compared real-time cooccurrence between boats and albatrosses, at different scales (100, 30 and $5 \mathrm{~km})$. We also examined to what extent co-occurrence at a large-scale $\left(5 \times 5^{\circ}\right.$ grid cell $)$ predicted fine-scale attendance $(5 \mathrm{~km})$.

Albatrosses on average spent about $3 \mathrm{~h}$ per trip attending fishing boats $(<5 \mathrm{~km})$ at both Amsterdam and Marion and about $30 \mathrm{~h}$ per trip at Kerguelen. In all populations $>90 \%$ of declared fishing boat attendance occurred within Economic Exclusive Zones (EEZ) where bycatch mitigation measures are more strictly enforced. Outside EEZs, birds from all populations also significantly attended non-fishing boats. Fishing boat density at large scales $\left(5 \times 5^{\circ}, 100 \mathrm{~km}\right)$ poorly predicted time spent attending fishing boats $(<5 \mathrm{~km})$ across populations

Our results indicate a large variation in fishing boat density within foraging ranges of different populations, and in time spent attending boats. We discuss the pros and cons of using large-scale analyses and how they might be improved to better estimate bycatch risks in seabirds when fine-scale data is available particularly for conservation purpose on those highly threatened species. 
Key words: albatross populations; biologging; bycatch assessment; ecological trap; fine-scale interaction; fisheries.

\section{Introduction}

In marine ecosystems, together with climate change, industrial fisheries constitute the main driver of ecological deterioration (Pauly et al., 2002). Fisheries interact with marine predators mainly by competing for resources (Cury et al., 2011; Grémillet et al., 2018) and by inducing mortality through bycatch of non-target species (Lewison et al., 2004). Fisheries can also facilitate access to prey for higher predators or provide additional food resources (Oro et al., 2013). For all these reasons many species of seabirds and marine mammals are attracted to fishing boats (Votier et al., 2004; Read, 2008; Brothers et al., 2010; Bugoni, McGill, \& Furness, 2010) in search of foraging opportunities associated with fishing bait or discards (Votier et al., 2004; Bicknell et al., 2013a). However, the associated bycatch is one of the primary threats for seabird populations around the world (Croxall et al., 2012). Moreover in some seabird populations the poor quality of these food resources negatively affect reproductive success (Gremillet et al., 2008; Le Bot, Lescroël, \& Grémillet, 2018a). Another concern is that populations heavily reliant on fishing vessels for food resources may be negatively impacted by changes in fishing policies (Bicknell et al., 2013b).

Bycatch is the most important threat for albatrosses and large petrels while at sea with high levels of mortality often induced by long-line fisheries (Delord et al., 2005; Anderson et al., 2011; Croxall et al., 2012). In the Southern Ocean, albatrosses overlap extensively with long-line fisheries, targeting tuna in oceanic waters, and various species of bottom-dwelling fishes over shelves and shelf-edges, in international waters as well as the Economic Exclusive Zones (EEZ) of the respective countries. The extent of spatio-temporal overlap between different fisheries and albatross foraging grounds has been inferred to represent mortality risk 
for various populations (Bertrand et al., 2012; Clay et al., 2019; Heerah et al., 2019).

However, information on fisheries location is generally available at a large scale, especially in international waters. For example, global fishing efforts provided by Regional Fisheries Management Organisations for tuna and billfishes is only available at a monthly and by $5 \times 5^{\circ}$ cell resolution (Clay et al., 2019; Heerah et al., 2019). This approach ignores the possibility that fisheries and seabirds could co-occur at a large scale without birds interacting with the fishing boats, particularly if they are not attracted by vessels (Clark et al., 2020). To better estimate mortality risk it is therefore necessary to complement these approaches with more direct information on the actual time birds spend attending fishing boats and how this varies spatially (Torres et al., 2013). This has been hampered in the past by difficulties in obtaining fine scale information on fishing vessel movements from fishing operators or authorities, with Vessel Monitoring System (VMS) information often being confidential (Votier et al., 2010) and restricted to confined EEZ territories.

In the Indian Ocean, large active longline tuna and Patagonian toothfish (Dissostichus eleginoides) fisheries (Delord et al., 2005) overlap with the foraging ranges of the two large albatross species (wandering - Diomedea exulans and Amsterdam - Diomedea amsterdamensis) breeding in the region (Henri Weimerskirch, Brothers, \& Jouventin, 1997; Delord et al., 2005). The past decline of the former species has been attributed to bycatch associated with long-line fisheries (Brothers, 1991; Henri Weimerskirch, Brothers, \& Jouventin, 1997; Nel et al., 2002). Despite mitigation measures that have been implemented by toothfish longline fisheries within the EEZs, which has resulted in a reduction in bycatch by this fishery (Delord et al., 2005; Henri Weimerskirch et al., 2018), there are still concerns of bycatch risk from long line fisheries and/or illegal or uncontrolled fisheries targeting tuna in international waters within this region (Brothers, 1991; Henri Weimerskirch, Brothers, \& Jouventin, 1997; H. Weimerskirch et al., 2020). Moreover, within more regulated EEZ waters 
it is important to estimate the extent to which albatrosses of different species and populations spend interacting with toothfish long-liners, to better quantify potential sub-lethal issues of dependence and possibly poor foraging quality (Bicknell et al., 2013a; Le Bot, Lescroël, \& Grémillet, 2018b).

In this study, we combined a large tracking data set of foraging albatrosses $(\mathrm{H}$.

Weimerskirch et al., 2020) with the locations and types of all declared boats from Automatic Identification System (AIS) in the southern Indian Ocean. GPS tracking data were collected in $2018 / 2019$ on breeding adults from all four major populations of large albatrosses in the Indian Ocean. We spatio-temporally matched these datasets to estimate the degree of cooccurrence at various scales from seascape $(<100 \mathrm{~km})$, through encounter $(<30 \mathrm{~km})$ to attendance $(<5 \mathrm{~km})$, following Weimerskirch et al. (2020). We particularly focused on the time spent attending fishing boats $(<5 \mathrm{~km})$ as a potential proxy for bycatch and other boatassociated risks. We examined how it differed among individuals and populations, how it differed with different types of fishing and non-fishing boats present during the breeding season, and how it differed between EEZs around subantarctic islands and international waters where different fisheries operate with different mitigation measures. Finally, to assess to what extent co-occurrence at a larger-scale reflects co-occurrence at finer-scale and could be used as a proxy for bycatch risk, we compared the time spent attending fishing boats $(<5 \mathrm{~km})$ to the encounter rate $(30 \mathrm{~km})$ and the density of boats in the seascape $(<100 \mathrm{~km})$ as well as to another, more widely used method of aggregating boat data by Regional Fisheries Management Organisations (RFMO) $5 \times 5^{\circ}$ grid. We 1) hypothesized that there is a large variation in the levels of exposure to boats according to albatrosses' foraging zones and range, 2) tested to what extent it resulted in variation in the time spent attending boats and 3) tested whether large scale $5 \times 5^{\circ}$ grid methods provide an adequate reflection of the attendance to 
119 boats and therefore the risk of bycatch. We then discuss implications for bycatch and sub-

120 lethal risks to the different populations.

122 Materials and methods

$123 \quad$ Field sites

124 Fieldwork was carried out in French southern territory (Crozet, Kerguelen \& Amsterdam)

125 during the course of a large-scale Ocean Sentinel program between January and April within

126 the 2018/2019 breeding season of large albatrosses in the Southern Indian Ocean (H.

127 Weimerskirch et al., 2020). We deployed loggers on wandering albatrosses at Possession

128 Island (Crozet Islands) and at the Kerguelen Islands, and on Amsterdam albatrosses at

129 Amsterdam Island. During the same incubation season GPS loggers were deployed on

130 wandering albatrosses on South Africa's Marion Island, Prince Edward Islands.

\section{$131 \quad \underline{\text { Loggers }}$}

132 On Crozet, Kerguelen and Amsterdam, Centurion loggers (65g) recording GPS location every

1332 min were deployed on incubating birds for one or two successive foraging trips $(\mathrm{H}$.

134 Weimerskirch et al., 2020). On Marion, GPS loggers (IgotU, 60g) recording locations every

13520 min were deployed for several trips during the incubation and brooding period. The

136 loggers were attached to the back feathers with Tesa ${ }^{\circledR}$ Tape (Germany), and represented

137 between 0.5 and $0.85 \%$ of large albatross body mass, much less than the maximum $3 \%$

138 recommended for loggers attached on flying seabirds (Phillips, Xavier, \& Croxall, 2003). 
140 A total of 143 trips on incubating albatrosses was recorded, with 57 trips from 27 individuals

141 on Marion Island, 10 trips from 8 individuals at Amsterdam, 49 trips from 49 individuals at

142 Crozet and 27 trips from 24 individuals at Kerguelen.

After using speed filters (150 km.h-1; Weimerskirch et al., 2020), we divided tracks

144 by trips (removing location on land) and we only used trips from the incubation period.

AIS data for all fishing and non-fishing boats (Fig. S1) were obtained from French satellite transmission society (Collecte Localisation Satellites) for the study period for the sector $10^{\circ}-180^{\circ} \mathrm{E}, 20^{\circ}-70^{\circ} \mathrm{S}$ through the Ocean sentinel program $(\mathrm{H}$. Weimerskirch et al., 2020), providing a total of 120 million AIS locations. Through the AIS system, in addition to regular GPS locations (mean resolution of $10 \mathrm{~min}$ ) we obtained continuous data on identification name, nationality, type of boat (fishing or not), and activity for all declared boats in the Southern Indian Ocean. AIS data and bird locations were spatio-temporally matched following Weimerskirch et al. (2020) to produce a dataset where all GPS locations of each bird from each population are associated to the presence/absence, number and types of 154 boats transmitting AIS information within ranges of 100, 30 and $5 \mathrm{~km}$ from birds. These different radius distances from birds are used to characterize the 'boat seascape' 156 (within 100 kilometres around the tracked bird), the 'boats encountered' $(30 \mathrm{~km})$ and the 157 'boats attended' $(5 \mathrm{~km})$. The $30 \mathrm{~km}$ distance was used as it is the distance within which an 158 albatross can visually detect a boat (Thiebault et al., 2014; J Collet, Patrick, \& Weimerskirch, 159 2015; Pirotta et al., 2018). The 5km threshold is close to the distance at which wandering 160 albatrosses are seen to engage in specific foraging behaviour around boats $(3 \mathrm{~km}$; Collet et al., 1612015 ) and is used to facilitate comparisons with previous studies that used radar detectors 162 with a range detection of $5 \mathrm{~km}$ (Weimerskirch et al., 2020, 2017). 
We defined 'events' (attendance and encounter events) as periods of consecutive bird

164 locations within the respective distances of at least one boat with time gap less than 2 hours.

165 To compare sites, and accommodate the relatively coarse scale GPS sampling at Marion

166 Island, we removed all events (attendance and encounter) lasting less than $20 \mathrm{~min}$. This

167 procedure also limits the effects of uncertainties on "instantaneous" bird-boat distances $(\mathrm{H}$.

168 Weimerskirch et al., 2020). We also removed the few incomplete trips for presenting trip

169 statistics (Table 1).

To compare with other studies using large scales $5 \times 5^{\circ}$ of fishing effort provided by

171 RFMOs (Clay et al., 2019; Heerah et al., 2019), we merged all AIS locations present during

172 the study period within grid cells of $5 \times 5^{\circ}$ (Fig. S1).

\section{$173 \quad$ Environmental variables}

174 AIS data do not provide detailed information on the type of fishing gears nor the mitigation

175 measures employed by fishing boats. We tried to further infer these information from the

176 waters they operated in. We added bathymetry data to each bird location (R package

177 'marmap', Pante and Simon-Bouhet, 2013), which was extracted from 'ETOPO1 Global

178 Relief Model' from 'National Oceanic and Atmospheric). We used it to categorize bird

179 locations as on a shelf or a shelf-edge (above $-2000 \mathrm{~m}$ ), where mainly benthic fishes are

180 targeted, or not, where tunas are the main target. We also considered whether locations were

181 within EEZ or not (data from http://www.marineregions.org) and separately considered the

182 time in attendance for specific EEZs with enforced mitigation measures within the range of

183 our populations (Crozet, Kerguelen, Heard, McDonald Saint-Paul and Amsterdam Islands).

184 Finally, from estimates of the locations of the polar front (Moore, Abbott, \& Richman, 1999)

185 and the subtropical front (Belkin \& Gordon, 1996) we further categorized bird locations into

186 Antarctic, subantarctic and subtropical waters. 
188 For visualization purposes, we used kernel Utilization Distributions (UDs 50 and 90\%), using the R package 'adehabitatHR' (smoothing parameters, $\mathrm{h}=1$ degree).

191 mixed model or generalized linear mixed models (depending on the distribution, using $\mathrm{R}$

192 package "fitdistrPlus"). Negative binomial family were used for over-dispersed count data

193 and binomial family for ratio data (R packages 'lme4' and 'lmerTest"). Bird individual

194 identities were used as random factors. We further used post-hoc tests (Tukey tests, R

195 package multicomp) and Holm-Bonferroni correction for $\mathrm{P}$ values. We used $\mathrm{Chi}^{2}$ test to

196 compare distributions of the number of trips with or without boat interaction between

197 populations.

To compare AIS data to time birds spent per $5 \times 5^{\circ}$ grid, we summed AIS locations (for

199 all types of boat or only for fishing boat) per grid cell used by each study population during their respective incubation-period months (April for Amsterdam birds, January and February for Crozet and Kerguelen birds, and February and March for Marion birds). Then, we used Pearson correlation to examine whether those aggregated AIS data are related to the time spent by birds in general, with boats in their seascape $(<100 \mathrm{~km})$, with boats encountered $204(<30 \mathrm{~km})$ and with boats attended $(<5 \mathrm{~km})$ in the same $5 \times 5^{\circ}$ grid cells.

\section{Results}

207 For the 143 trips recorded during incubation, there were no significant differences between 208 populations in the duration of foraging trips but mean maximum distance from the colony 209 differed between Kerguelen (shortest) and Marion (longest) (Table 1). 
Birds from Kerguelen spent more time foraging within EEZs $(74 \% \pm 32$, Table 1) than

211 birds from Crozet $(57 \% \pm 35)$, Amsterdam $(39 \% \pm 41)$ and Marion $(36 \% \pm 24)$. Amsterdam and

212 Marion birds spent less time foraging over shelf waters $(20 \% \pm 29$ and $11 \% \pm 15$ respectively)

213 as compared to Crozet $(40 \% \pm 33)$ and Kerguelen birds (65\% \pm 29$)$ (Fig. 1) (Table 1 and Table

214 S1 for test values).

Amsterdam albatrosses spent most of their time in subtropical waters $(97 \% \pm 07)$

216 whereas the three wandering albatross populations foraged mainly in subantarctic waters

$217(57 \% \pm 31$ to $78 \% \pm 30)$ (Fig. 1) (Table 1 and Table S1 for test values).

Among the 143 trips recorded, the percentages of trips with at least one boat within $100 \mathrm{~km}$ (boat seascape), were significantly different between populations, ranging from $68 \%$

to $100 \%\left(\mathrm{Chi}^{2}, 3=24.9 ; \mathrm{p}\right.$ value $\left.=1.5 \mathrm{e}-05\right)($ Table 2$)$. The percentage of trips with boats encountered (within $30 \mathrm{~km}$ ) also varied significantly between sites, from 63 to $85 \%\left(\mathrm{Chi}^{2}, 3=\right.$ 9.08; $p$ value $=0.028)($ Table 2$)$. Finally, the percentage of trips with attendance (within 5 $\mathrm{km})$ of boats were also significantly different between sites, varying from 47 to $73 \%\left(\mathrm{Chi}^{2}, 3\right.$

$224=8.01 ; \mathrm{p}$ value $=0.046)($ Table 2$)$

The number of encounters and attendance events per trip, when considering fishing

226 boats and other boats together (transport, tankers, etc.) was similar between populations

227 (Table 1 and Table S1 for test values). Kerguelen birds spent more time on average per trip 228 within $30 \mathrm{~km}$ of all types of boats $(53 \mathrm{~h} \pm 62)$, within $5 \mathrm{~km}$ of all type of boats $(31 \mathrm{~h} \pm 38)$ and

229 within $5 \mathrm{~km}$ of fishing boats $(30.6 \mathrm{~h} \pm 39)$ (Fig. 2a) than birds from other populations (Table 1

230 and Table S1 for test values). Similarly, Kerguelen birds spent significantly more time

231 attending boats inside EEZs (with mitigation measures) than birds from other populations.

232 However, outside EEZ (where mitigation measures are less controlled) the different 
populations spent similar time attending AIS-recorded boats of all types, and similar time attending AIS-recorded fishing boats (Table 1 and Table S1 for test values).

Based on all location, Amsterdam birds on average had the most number of boats $(1.9 \pm 5)$ and the most number of fishing boats $(0.83 \pm 1.9)$ in their seascapes $(<100 \mathrm{~km})$, at least twice as much as other populations (Table 1 and Table $\mathrm{S} 1$ for test values). However at Kerguelen birds on average had the most number of boat encounters $(<30 \mathrm{~km}: 0.2 \pm 0.4)$, the most number of boats attended $(<5 \mathrm{~km}: 0.1 \pm 0.3$, Fig. $2 \mathrm{~b})$ and the highest ratio of the number of boats attended relative to the number boats in the seascape $(0.3 \pm 0.5)$, most of the time by a factor of 5-10 fold compared to other populations (Table 1 and Table S1 for test values).

Marion and Amsterdam birds had a smaller proportion of fishing versus non-fishing boats in their seascapes $(<100 \mathrm{~km})$ compared to other populations (Table 1 and Table S1 for test values). Marion birds had a significantly lower proportion of fishing boats among encountered boats $(<30 \mathrm{~km})$ than Crozet and Kerguelen and slightly less than Amsterdam. The proportion of fishing boats among attended boats $(<5 \mathrm{~km})$ was not different between Marion, Amsterdam and Crozet birds $(0.22 \pm 0.4,0.64 \pm 0.4$ and $0.76 \pm 0.4$, respectively), but it was lower than for Kerguelen birds $(0.95 \pm 0.2$, Table 1 and Table S1 for test values).

Finally, we found that at all locations, birds attended only a small proportion of the total number of boats in their seascapes: $30 \% \pm 45$ for Kerguelen birds which was significantly higher than for Crozet birds $(7 \% \pm 24)$ and for Marion and Amsterdam birds $(4 \% \pm 0.19$; Table 1 and Table S1 for test values).

For all four populations, there were no significant correlations between the time spent by birds per $5 \times 5^{\circ}$ grid cells (in general, with boats in their seascape, with boats encountered and with boats attended) and between the number of AIS signals per $5 \times 5^{\circ}$ grid cells. This 
applied when considering all types of boats as well as fishing boats only (Table 3 and Fig.

257 S1).

\section{Discussion}

260 Our study clearly indicates strong differences between populations in the time spent attending 261 boats, with different associated bycatch risks (Fig. 2a). Furthermore, we clearly show that these 262 variations in time spent attending boats are not a simple linear function of the density of boats 263 in the seascape, as previous methods aimed at assessing bycatch risk have assumed. Indeed, we 264 have shown that using AIS data combined with fine scale GPS tracking of seabirds can provide a considerably more reliable estimate of bycatch risks, through the documentation of the actual time birds spend interacting at a fine scale with different types of declared boats. Indeed, most previous studies used monthly maps of the number of hooks deployed within aggregated $5 \times 5^{\circ}$ cells (around 560x560km in our region) to estimate risks incurred by foraging birds (Clay et al., 2019; Heerah et al., 2019), but here we show that analyses at this scale do not correlate at all with time spent interacting with boats.

Overall, we found that all four populations spent considerably more time attending fisheries boats within EEZs (with bycatch mitigation measures) than in international waters. On average, birds from all populations spent less than $1 \mathrm{~h}$ per trip attending declared fishing boats outside EEZs where bycatch mitigation measures are generally adopted leading to low seabirds' mortalities. While it means that at least 3 out of the 4 studied populations are indeed at risk of bycatch from these declared fleets outside EEZs (where no bycatch mitigation measures are taken), birds seem to spend limited time attending them. Important to note is that this result could potentially be very different if non-declared boats (without AIS) could also be included.

279 Indeed, illegal, undeclared and unregulated fleets may represent up to $30 \%$ of boat encounters 
for breeding large albatrosses (H. Weimerskirch et al., 2020). The lack of information on these

281 boats can partly be remedied by using new loggers that can detect radar emission of boats up to $2825 \mathrm{~km}$ away (Weimerskirch, Filippi, Collet, Waugh, \& Patrick, 2017). However, AIS data 283 provides additional information on boat identity and also on a larger scale boat seascape around 284 birds, so that more accurate results could be reached by combining the two methods (radar 285 detectors were not available for Marion birds in the present study).

AIS data revealed that the four populations of large albatrosses breeding within the Indian Ocean foraged in very different boat seascapes. Yet, the time spent interacting with 288 fishing boats within or beyond EEZs could not be predicted by the respective boat densities with the foraging ranges of the different populations. Fishing boats in the area mainly fall within two categories: toothfish longline fisheries operating on subantarctic shelves and tuna longlining fisheries operating in subtropical waters (Corbeau et al., 2019). In addition, many non-fishing boats (cargo, tankers) transit through subtropical waters between Africa, Asia and 293 Australia. Birds from Marion had the least contact with boats, with a large proportion of trips without boat encounters, yet most attended boats were not associated with fisheries. This can potentially be explained by the absence of a surrounding shelf and the small scale of the declared toothfish fishery in the region in comparison to Crozet and Kerguelen $(\mathrm{H}$. Weimerskirch et al., 2020). Furthermore, birds from Marion spent a relatively low proportion 298 of their foraging time in subtropical waters (in contrast to Amsterdam birds). At the opposite end, Amsterdam birds ranged in the densest boat seascape, both in terms of the general boat density and in terms of fishing boats density. This is of particular concern for this endangered

301 species with less than 60 pairs breeding annually on Amsterdam Island (Thiebot et al., 2015; 302 Heerah et al., 2019). Yet, birds from Marion and Amsterdam populations eventually spent very 303 similar average amounts of time with declared fishing boats both within or outside EEZs (with 304 different bycatch mitigation measures). In contrast, compared to Marion and Amsterdam 
populations, Kerguelen birds spent considerably more time with fishing boats and mostly within

306 EEZs with much lower boat densities and Crozet birds appeared to spend more time with fishing boats both outside and within EEZs. Moreover, we have shown that large-scale overlap analyses $\left(5 \times 5^{\circ}\right)$ of AIS data was not related to the proxy of fine-scale bycatch risk (Table 3 ). It is therefore very clear that the density of (fishing) boats within the foraging range does not linearly translate into time spent attending boats.

This discrepancy between boat density in the foraging range of seabirds and the actual

312 time birds spent attending fishing boats calls for caution when estimating bycatch risk from 313 large-scale overlap data. AIS data is costly but it may be more easily accessible to researchers 314 than the often confidential and geographically-restricted VMS data (Votier et al., 2010) to allow 315 for fine-scale analyses. However large-scale overlap analyses will still be needed in particular 316 when bird tracking data is available at lower resolution than that offered by GPS tracking 317 devices (Clay et al., 2019a). This may be the case for many studies using GLS devices on non318 breeding individuals (juveniles, failed breeders, adults in winter or on sabbatical, etc.) or for small species for which relatively large GPS device deployment could be problematic (Le Corre et al., 2012; Delord et al., 2014). It would thus be useful to understand why a higher boat density does not necessarily translate into more time spent by seabirds attending boats, and under what circumstances this applies, to improve bycatch risk estimation from large-scale data.

An intriguing consideration raised by our results relevant to improving bycatch risk estimations from large-scale data, is what we may call the dilution-shield hypothesis. An increasing boat density may increase the encounter probability (Julien Collet, Patrick, \& 326 Weimerskirch, 2017), but when a bird starts to attend and exploit a boat it reduces its exploration time and chances of encountering further boats. Indeed, we clearly show that the

328 densest the boat seascape is, the lower the ratio of all boats in the seascape being actually 329 approached by birds (Table 1). Beyond a certain value, boat density may become less important 
to consider than which boat(s) birds are attending. In the Mediterranean Sea, shearwaters were

331 observed to interact less with longliners when trawlers were present than when trawlers were 332 absent (Soriano-Redondo et al., 2016). In our study, Amsterdam albatrosses ranged by far in 333 the densest fishing boat seascape, but also in the densest non-fishing boat seascape. In contrast, 334 Kerguelen birds did not range in a very dense fishing boat area, but virtually all boats on the 335 Kerguelen shelf are fishing boats (Table 1). If birds are not strongly selective on the boats they 336 attend after encounters, non-fishing boats might dilute the bycatch risk and act as a shield 337 against more dangerous boats. Indeed we found that outside of EEZs, birds spent most of their 338 time in attendance of boats not associated with fisheries: 100\% for Kerguelen, 93\% for 339 Amsterdam, 81\% for Marion and 35\% for Crozet (within EEZs only fishing boats were 340 identified). Moreover, within all four populations, the ratio of fishing in relation to non-fishing 341 boats remained relatively similar across the three investigated scales $(5,30$ and $100 \mathrm{~km}$, Table 342 1), suggesting low selectivity. It may be worth further investigating this hypothesis because if 343 this is correct, bycatch risk estimations from large scale overlap data (Clay et al., 2019; Heerah 344 et al., 2019) might relatively easily be improved by considering not only fishing boat density 345 but also non-fishing boat density within the foraging ranges of seabirds.

346 Boats may also cause other non-lethal issues beyond bycatch (nutritional and/or 347 dependence issues), especially if they become an important part of birds' time budgets (Fig. 2b) 348 and/or diet. To our knowledge, there are very few studies that have looked at how fisheries349 independent boats may impact foraging success and behavior in seabirds. However, it seems 350 that our studied birds spent a low fraction of their foraging time attending them. Of greater 351 concern is the large amount of time Kerguelen birds seem to spend attending the toothfish 352 longline fishery operating around their breeding ground. The nature, quality and amount of food 353 albatrosses can obtain from these toothfish fisheries are unclear considering bycatch mitigation 
measures that are implemented. However, Kerguelen birds appear to be more dependent on these boats than the most studied Crozet population.

An important question about bycatch risk is whether the large differences we observe in the time incubating birds spent attending different types of fishing boats across populations may be related to differences in population trends. Amsterdam albatrosses have been increasing since the 1980s at a high rate, suggesting that they suffer minimal if any mortality from fisheries (Rivalan, Barbraud, Inchausti, \& Weimerskirch, 2010; Weimerskirch et al., 1997). Although they forage in zones with high densities of both fishing and non-fishing boats, birds do not seem to be particularly attracted by fishing boats: the low interaction to boats may explain why this population has been able to increase steadily over the past four years. The three other populations have shown similar trends until about 15 years ago, with a steep decline in the 1970s and early 1980 followed by a partial recovery (Nel et al., 2002; Weimerskirch et al., 1997). Since then, the population on Marion has been increasing, whereas Kerguelen and Crozet populations are stable (Ryan, Jones, Dyer, Upfold, \& Crawford, 2009; Weimerskirch et al., 2018). This difference in population dynamics of the wandering albatross populations could be related to the lower encounter and attendance rates of Marion birds compared to Crozet and Kerguelen birds.

Seabirds are one of the animal groups with the largest proportion of threatened species and there has been much effort globally to better understand causative mechanisms behind declining populations for conservation purposes. In this paper, we proposed a simple method for estimating fine scale interactions between seabirds and boats with AIS. This method is easily implemented through the combination of seabirds GPS tracks, now routinely collected 
377 globally (Burger \& Shaffer, 2008; Le Corre et al., 2012), and AIS data, which is readily

378 available (International Maritime Organisation).

With this method we provided the most direct and comprehensive assessment to date

380 of bycatch risk for large albatrosses breeding in the Indian Ocean, including for one of the

381 most threatened bird species. We illustrated the pros and cons of using AIS data for such

382 estimations, compared to other existing methods (large-scale overlap analyses and/or use of

383 embarked radar detectors). Importantly we showed that fishing boat density may not be a

384 good proxy to predict time spent attending boats and bycatch risk, and we proposed a general

385 hypothesis of shield effect from other types of boats to explain this discrepancy. Our results

386 also reveal extensive variations in the time and proportion of foraging time populations spent

387 attending various types of boats, which may cause other non-lethal issues beyond bycatch

388 risks, especially in the Kerguelen population.

\section{Acknowledgements}

391 The study is a contribution to the Program EARLYLIFE funded by a European Research

392 Council Advanced Grant under the European Community's Seven Framework

393 Program FP7/2007-2013 (Grant Agreement ERC-2012-ADG_20120314 to Henri

394 Weimerskirch) and to the Program Ocean Sentinel funded by the ERC under European

395 Community's H2020 Program (Grant Agreement ERC-2017-PoC_780058 to HW). The

396 fieldwork was also funded by program IPEV $\mathrm{n}^{\circ}$ 109. South Africa's Department of

397 Environmental Affairs provided logistical support for fieldwork on Marion Island, which was

398 funded through the South African National Research Foundation (grant SNA93071 to Pierre

399 Pistorius). 
400 Field procedures on Crozet, Kerguelen and Amsterdam were supported by the 'Préfet of

401 Terres Australes et Antarctiques Françaises'. We thank the Reserve Nationale des TAAF for 402 funding loggers deployed on Amsterdam Island. We thank the fieldworkers involved in the

403 study on four sites, in particular Florent Lacoste, Tobie Getti, Aude Schreiber, Jérémy

404 Dechartre, Yusuke Goto, Yoshi Yonehara, Danielle and Stephan Keys. We thank Adrien

405 Pajot, for the help with AIS data. We thank the house 'Ici c'est Olbreuse' for providing

406 accommodation and fruitful discussions to half of the authors.

\section{Data accessibility}

408 Data are available in figshare at doi: 10.6084/m9.figshare.10289096 (Weimerskirch, Collet, 409 Corbeau, Pajot, Hoarau, Marteau, Filippi, Patrick, et al., 2019)

\section{Authors' contributions}

411 HW conceived the project, AC, JC, FO, HW and PP contributed data and/or did field work 412 and prepared the data, JC merged AIS data to tracking data, AC performed all the other 413 analyses, AC and HW wrote the original paper and all authors commented on earlier drafts.

\section{References}

416 Anderson, O., Small, C., Croxall, J., Dunn, E., Sullivan, B., Yates, O., \& Black, A. (2011). 417 Global seabird bycatch in longline fisheries. Endanger. Species Res. 14, 91-106. 418 Belkin, I. M., \& Gordon, A. L. (1996). Southern Ocean fronts from the Greenwich meridian to Tasmania. J. Geophys. Res. Oceans 101, 3675-3696.

420 Bertrand, S., Joo, R., Arbulu Smet, C., Tremblay, Y., Barbraud, C., \& Weimerskirch, H. (2012). Local depletion by a fishery can affect seabird foraging. (M. Frederiksen, Ed.)J. Appl. Ecol. 49, 1168-1177. 
Bicknell, A. W. J., Oro, D., Camphuysen, K. C. J., \& Votier, S. C. (2013a). Potential consequences of discard reform for seabird communities. (J. Blanchard, Ed.)J. Appl. Ecol. 50, 649-658.

Bicknell, A. W. J., Oro, D., Camphuysen, K. C. J., \& Votier, S. C. (2013b). Potential consequences of discard reform for seabird communities. (J. Blanchard, Ed.)J. Appl. Ecol. 50, 649-658.

Brothers, N. (1991). Albatross mortality and associated bait loss in the Japanese longline fishery in the Southern Ocean. Biol. Conserv. 55, 255-268.

Brothers, N., Duckworth, A. R., Safina, C., \& Gilman, E. L. (2010). Seabird Bycatch in Pelagic Longline Fisheries Is Grossly Underestimated when Using Only Haul Data. (S. J. Bograd, Ed.)PLoS ONE 5, e12491.

Bugoni, L., McGill, R. A. R., \& Furness, R. W. (2010). The importance of pelagic longline fishery discards for a seabird community determined through stable isotope analysis. J. Exp. Mar. Biol. Ecol. 391, 190-200.

Burger, A. E., \& Shaffer, S. A. (2008). APPLICATION OF TRACKING AND DATALOGGING TECHNOLOGY IN RESEARCH AND CONSERVATION OF SEABIRDS. The Auk 125, 253-264.

Clark, B. L., Vigfúsdóttir, F., Jessopp, M. J., Burgos, J. M., Bodey, T. W., \& Votier, S. C. (2020). Gannets are not attracted to fishing vessels in Iceland-potential influence of a discard ban and food availability. (K. Camphuysen, Ed.)ICES J. Mar. Sci. 77, 692700.

Clay, T. A., Small, C., Tuck, G. N., Pardo, D., Carneiro, A. P. B., Wood, A. G., Croxall, J. P., Crossin, G. T., \& Phillips, R. A. (2019). A comprehensive large-scale assessment of fisheries bycatch risk to threatened seabird populations. (V. Paiva, Ed.)J. Appl. Ecol. 
Collet, J, Patrick, S., \& Weimerskirch, H. (2015). Albatrosses redirect flight towards vessels at the limit of their visual range. Mar. Ecol. Prog. Ser. 526, 199-205.

Collet, Julien, Patrick, S. C., \& Weimerskirch, H. (2017). Behavioral responses to encounter of fishing boats in wandering albatrosses. Ecol. Evol. 7, 3335-3347.

Corbeau, A., Collet, J., Fontenille, M., \& Weimerskirch, H. (2019). How do seabirds modify their search behaviour when encountering fishing boats? (D. Hyrenbach, Ed.)PLOS ONE 14, e 0222615.

Croxall, J. P., Butchart, S. H. M., Lascelles, B., Stattersfield, A. J., Sullivan, B., Symes, A., \& Taylor, P. (2012). Seabird conservation status, threats and priority actions: a global assessment. Bird Conserv. Int. 22, 1-34.

Cury, P. M., Boyd, I. L., Bonhommeau, S., Anker-Nilssen, T., Crawford, R. J. M., Furness, R. W., Mills, J. A., Murphy, E. J., Osterblom, H., Paleczny, M., Piatt, J. F., Roux, J.-P., Shannon, L., \& Sydeman, W. J. (2011). Global Seabird Response to Forage Fish Depletion--One-Third for the Birds. Science 334, 1703-1706.

Delord, K., Barbraud, C., Bost, C. A., Cherel, Y., Guinet, C., \& Weimerskirch, H. (2014). Atlas of top predators from French Southern Territories in the Southern Indian Ocean. CNRS.

Delord, K., Gasco, N., Weimerskirch, H., Barbraud, C., \& Micol, T. (2005). Seabird mortality in the Patagonian toothfish longline fishery around Crozet and Kerguelen Islands, 2001-2003. Ccamlr Sci. 12, 53-80.

Gremillet, D., Pichegru, L., Kuntz, G., Woakes, A. G., Wilkinson, S., Crawford, R. J. M., \& Ryan, P. G. (2008). A junk-food hypothesis for gannets feeding on fishery waste. Proc. R. Soc. B Biol. Sci. 275, 1149-1156. 
Grémillet, D., Ponchon, A., Paleczny, M., Palomares, M.-L. D., Karpouzi, V., \& Pauly, D. (2018). Persisting Worldwide Seabird-Fishery Competition Despite Seabird Community Decline. Curr. Biol. 28, 4009-4013.e2.

Heerah, K., Dias, M. P., Delord, K., Oppel, S., Barbraud, C., Weimerskirch, H., \& Bost, C. A. (2019). Important areas and conservation sites for a community of globally threatened marine predators of the Southern Indian Ocean. Biol. Conserv. 234, 192-201.

Le Bot, T., Lescroël, A., \& Grémillet, D. (2018a). A toolkit to study seabird-fishery interactions. (S. Votier, Ed.)ICES J. Mar. Sci. 75, 1513-1525.

Le Bot, T., Lescroël, A., \& Grémillet, D. (2018b). A toolkit to study seabird-fishery interactions. (S. Votier, Ed.)ICES J. Mar. Sci. 75, 1513-1525.

Le Corre, M., Jaeger, A., Pinet, P., Kappes, M. A., Weimerskirch, H., Catry, T., Ramos, J. A., Russell, J. C., Shah, N., \& Jaquemet, S. (2012). Tracking seabirds to identify potential Marine Protected Areas in the tropical western Indian Ocean. Biol. Conserv. 156, 8393.

Lewison, R., Crowder, L., Read, A., \& Freeman, S. (2004). Understanding impacts of fisheries bycatch on marine megafauna. Trends Ecol. Evol. 19, 598-604.

Moore, J. K., Abbott, M. R., \& Richman, J. G. (1999). Location and dynamics of the Antarctic Polar Front from satellite sea surface temperature data. J. Geophys. Res. Oceans 104, 3059-3073.

Nel, Deon. C., Ryan, P. G., Nel, J. L., Klages, N. T. W., Wilson, R. P., Robertson, G., \& Tuck, G. N. (2002). Foraging interactions between Wandering Albatrosses Diomedea exulans breeding on Marion Island and long-line fisheries in the southern Indian Ocean: Foraging interactions in albatrosses. Ibis 144, E141-E154. 
Oro, D., Genovart, M., Tavecchia, G., Fowler, M. S., \& Martínez-Abraín, A. (2013).

Ecological and evolutionary implications of food subsidies from humans. (B. Worm, Ed.)Ecol. Lett. 16, 1501-1514.

Pante, E., \& Simon-Bouhet, B. (2013). marmap: A Package for Importing, Plotting and Analyzing Bathymetric and Topographic Data in R. (G. J.-P. Schumann, Ed.)PLoS ONE 8, e73051.

Pauly, D., Christensen, V., Guénette, S., Pitcher, T. J., Sumaila, U. R., Walters, C. J., Watson, R., \& Zeller, D. (2002). Towards sustainability in world fisheries. Nature 418, 689695.

Phillips, R. A., Xavier, J. C., \& Croxall, J. P. (2003). Effects of satellite transmitters on albatrosses and petrels. The Auk 120, 1082-1090.

Pirotta, E., Edwards, E. W. J., New, L., \& Thompson, P. M. (2018). Central place foragers and moving stimuli: A hidden-state model to discriminate the processes affecting movement. (L. Börger, Ed.)J. Anim. Ecol. 87, 1116-1125.

Read, A. J. (2008). The looming crisis: interactions between marine mammals and fisheries. $J$. Mammal. 89, 541-548.

Rivalan, P., Barbraud, C., Inchausti, P., \& Weimerskirch, H. (2010). Combined impacts of longline fisheries and climate on the persistence of the Amsterdam Albatross Diomedia amsterdamensis. Ibis 152, 6-18.

Ryan, P. G., Jones, M. G., Dyer, B. M., Upfold, L., \& Crawford, R. J. (2009). Recent population estimates and trends in numbers of albatrosses and giant petrels breeding at the sub-Antarctic Prince Edward Islands. Afr. J. Mar. Sci. 31, 409-417.

Soriano-Redondo, A., Cortés, V., Reyes-González, J. M., Guallar, S., Bécares, J., Rodríguez, B., Arcos, J. M., \& González-Solís, J. (2016). Relative abundance and distribution of fisheries influence risk of seabird bycatch. Sci. Rep. 6, 37373. 
Thiebault, A., Mullers, R. H. E., Pistorius, P. A., \& Tremblay, Y. (2014). Local enhancement in a seabird: reaction distances and foraging consequence of predator aggregations. Behav. Ecol. 25, 1302-1310.

Thiebot, J.-B., Delord, K., Barbraud, C., Marteau, C., \& Weimerskirch, H. (2015). 167 individuals versus millions of hooks: bycatch mitigation in longline fisheries underlies conservation of Amsterdam albatrosses: Amsterdam Albatrosses and Longline Fisheries. Aquat. Conserv. Mar. Freshw. Ecosyst. n/a-n/a.

Torres, L., Sagar, P., Thompson, D., \& Phillips, R. (2013). Scaling down the analysis of seabird-fishery interactions. Mar. Ecol. Prog. Ser. 473, 275-289.

Votier, S. C., Bearhop, S., Witt, M. J., Inger, R., Thompson, D., \& Newton, J. (2010). Individual responses of seabirds to commercial fisheries revealed using GPS tracking, stable isotopes and vessel monitoring systems. J. Appl. Ecol. 47, 487-497.

Votier, S. C., Furness, R. W., Bearhop, S., Crane, J. E., Caldow, R. W. G., Catry, P., Ensor, K., Hamer, K. C., Hudson, A. V., Kalmbach, E., Klomp, N. I., Pfeiffer, S., Phillips, R. A., Prieto, I., \& Thompson, D. R. (2004). Changes in fisheries discard rates and seabird communities. Nature 427, 727-730.

Weimerskirch, H., Collet, J., Corbeau, A., Pajot, A., Hoarau, F., Marteau, C., Filippi, D., \& Patrick, S. C. (2020). Ocean sentinel albatrosses locate illegal vessels and provide the first estimate of the extent of nondeclared fishing. Proc. Natl. Acad. Sci. 201915499.

Weimerskirch, H., Collet, J., Corbeau, A., Pajot, A., Hoarau, F., Marteau, C., Filippi, D., Patrick, S. C., Pistorius, P., Orgeret, F., \& Joo, R. (2019). Data_OCEAN_SENTINEL_Weimerskirch_et_al_2018_2019.Figshare - Dataset . Weimerskirch, H., Filippi, D. P., Collet, J., Waugh, S. M., \& Patrick, S. C. (2017). Use of radar detectors to track attendance of albatrosses at fishing vessels: Seabird-Fishery Interactions. Conserv. Biol. 
543 Weimerskirch, Henri, Brothers, N., \& Jouventin, P. (1997). Population dynamics of wandering albatross Diomedea exulans and Amsterdam albatross D. amsterdamensis in the Indian Ocean and their relationships with long-line fisheries: conservation implications. Biol. Conserv. 79, 257-270.

547 Weimerskirch, Henri, Delord, K., Barbraud, C., Le Bouard, F., Ryan, P. G., Fretwell, P., \& Marteau, C. (2018). Status and trends of albatrosses in the French Southern Territories, Western Indian Ocean. Polar Biol. 41, 1963-1972.

550 


\section{Table}

52 Table 1 - Differences between each site: mean and standard deviation of parameters and significance letters of Tuckey tests (same letter in different site mean no 53 difference and different letters mean significant differences).

\begin{tabular}{|c|c|c|c|c|c|c|c|c|c|c|c|c|}
\hline & \multicolumn{3}{|c|}{$\begin{array}{c}\text { Amsterdam } \\
\text { (trips: } n=10,10 \text { complete) }\end{array}$} & \multicolumn{3}{|c|}{$\begin{array}{c}\text { Crozet } \\
\text { (trips: } n=49,48 \text { complete) }\end{array}$} & \multicolumn{3}{|c|}{$\begin{array}{c}\text { Kerguelen } \\
\text { (trips: } n=27,23 \text { complete) }\end{array}$} & \multicolumn{3}{|c|}{$\begin{array}{c}\text { Marion } \\
\text { (trips: } n=57,53 \text { complete) }\end{array}$} \\
\hline & Mean & $\begin{array}{l}\text { Standard } \\
\text { deviation }\end{array}$ & $\begin{array}{c}\text { Significance } \\
\text { letter }\end{array}$ & Mean & $\begin{array}{l}\text { Standard } \\
\text { deviation }\end{array}$ & $\begin{array}{c}\begin{array}{c}\text { Significance } \\
\text { letter }\end{array} \\
\end{array}$ & Mean & $\begin{array}{l}\text { Standard } \\
\text { deviation } \\
\end{array}$ & $\begin{array}{c}\text { Significance } \\
\text { letter }\end{array}$ & Mean & $\begin{array}{l}\text { Standard } \\
\text { deviation }\end{array}$ & $\begin{array}{c}\text { Significance } \\
\text { letter }\end{array}$ \\
\hline \multicolumn{13}{|c|}{ PER TRIP ( $n=143)$} \\
\hline Maximum distance from the colony (km) & 1637.70 & 1281.10 & $A B$ & 1177.90 & 813.90 & $\mathrm{AB}$ & 886.60 & 711.85 & A & 1424.70 & 660.54 & $\mathrm{~B}$ \\
\hline Trip duration (day) & 9.53 & 3.48 & A & 11.09 & 5.60 & A & 10.60 & 4.14 & A & 12.60 & 4.46 & $\mathrm{~A}$ \\
\hline Ratio in EEZ & 0.39 & 0.41 & $\mathrm{AC}$ & 0.57 & 0.35 & $\mathrm{AB}$ & 0.74 & 0.32 & $\mathrm{~B}$ & 0.36 & 0.24 & $\mathrm{C}$ \\
\hline Ratio on shelf & 0.20 & 0.29 & $\mathrm{AC}$ & 0.40 & 0.33 & A & 0.65 & 0.29 & $\mathrm{~B}$ & 0.11 & 0.15 & $\mathrm{C}$ \\
\hline Ration in Antarctic waters & 0.00 & 0.00 & $\mathrm{~A}$ & 0.07 & 0.20 & $A$ & 0.19 & 0.30 & $A$ & 0.12 & 0.26 & A \\
\hline Ration in subantarctic waters & 0.03 & 0.07 & A & 0.72 & 0.34 & $\mathrm{~B}$ & 0.78 & 0.30 & $\mathrm{~B}$ & 0.57 & 0.31 & $\mathrm{~B}$ \\
\hline Ration in subtropical waters & 0.97 & 0.07 & $\mathrm{~A}$ & 0.21 & 0.32 & $\mathrm{BC}$ & 0.02 & 0.13 & $\mathrm{~B}$ & 0.31 & 0.32 & $\mathrm{C}$ \\
\hline Number of encounters & 5.10 & 7.61 & A & 3.06 & 2.18 & A & 2.89 & 2.65 & A & 4.23 & 5.45 & A \\
\hline Time in encounter (h) & 19.04 & 23.28 & A & 17.08 & 18.36 & A & 53.30 & 62.82 & $\mathrm{~B}$ & 11.91 & 21.96 & A \\
\hline Number of attendances & 1.80 & 2.20 & A & 1.71 & 1.57 & A & 3.59 & 4.41 & A & 1.72 & 2.70 & A \\
\hline Time in attendance $(\mathrm{h})$ & 4.31 & 6.97 & A & 6.75 & 11.00 & A & 31.14 & 38.22 & $\mathrm{~B}$ & 3.21 & 10.20 & A \\
\hline Time in attendance with fishing vessels (h) & 3.16 & 7.56 & A & 6.68 & 11.31 & A & 30.63 & 39.27 & $\mathrm{~B}$ & 2.64 & 10.31 & A \\
\hline Time in attendance in EEZ (h) & 2.90 & 6.71 & A & 5.84 & 11.14 & A & 28.37 & 38.60 & $\mathrm{~B}$ & 2.46 & 10.24 & A \\
\hline Time in attendance out EEZ (h) & 1.42 & 2.40 & A & 0.91 & 2.74 & A & 2.77 & 11.56 & A & 0.75 & 1.58 & A \\
\hline Time in attendance with fishing vessels in EEZ (h) & 2.82 & 6.75 & $\mathrm{~A}$ & 5.84 & 11.14 & A & 28.36 & 38.60 & $\mathrm{~B}$ & 2.45 & 10.24 & A \\
\hline Time in attendance with fishing vessels out EEZ (h) & 0.11 & 0.28 & A & 0.60 & 2.66 & A & 0.00 & 0.00 & A & 0.14 & 0.68 & A \\
\hline Ratio of fishing vessels attended $(5 \mathrm{~km})$ & 0.64 & 0.43 & $\mathrm{AB}$ & 0.76 & 0.42 & $A B$ & 0.95 & 0.23 & $\mathrm{~A}$ & 0.22 & 0.37 & $\mathrm{~B}$ \\
\hline Ratio of fishing vessels encountered $(30 \mathrm{~km})$ & 0.63 & 0.36 & $A B$ & 0.76 & 0.40 & A & 0.92 & 0.28 & A & 0.17 & 0.32 & $\mathrm{~B}$ \\
\hline Ratio of fishing vessels in seascape (100km) & 0.43 & 0.27 & A & 0.75 & 0.36 & $\mathrm{~B}$ & 0.92 & 0.23 & $\mathrm{~B}$ & 0.16 & 0.29 & A \\
\hline \multicolumn{13}{|c|}{ PER LOCATION (n=619631) } \\
\hline Number of boats attended $(5 \mathrm{~km})$ & 0.02 & 0.16 & A & 0.02 & 0.15 & A & 0.11 & 0.31 & $\mathrm{~B}$ & 0.01 & 0.11 & C \\
\hline Number of boats encountered (30km) & 0.19 & 0.84 & A & 0.06 & 0.26 & $\mathrm{~B}$ & 0.23 & 0.43 & C & 0.05 & 0.26 & $\mathrm{~B}$ \\
\hline Number of boats in seascape $(100 \mathrm{~km})$ & 1.99 & 5.08 & A & 0.29 & 0.60 & $\mathrm{~B}$ & 0.40 & 0.60 & C & 0.35 & 1.11 & $\mathrm{D}$ \\
\hline Number of fishing vessels in seascape (100km) & 0.83 & 1.93 & A & 0.21 & 0.51 & $\mathrm{~B}$ & 0.39 & 0.60 & C & 0.07 & 0.33 & $\mathrm{D}$ \\
\hline Ratio of number of boats $5 \mathrm{~km} / 100 \mathrm{~km}$ & 0.04 & 0.19 & $A$ & 0.07 & 0.24 & $A$ & 0.30 & 0.45 & $B$ & 0.04 & 0.18 & $A$ \\
\hline
\end{tabular}


55 Table 2 - Number (and percentage) of trips per site with boats in seascapes $(100 \mathrm{~km})$, encountered $(30 \mathrm{~km})$ and attended $(5 \mathrm{~km})$.

\begin{tabular}{|c|c|c|c|c|c|}
\hline & Amsterdam $(\boldsymbol{n}=\mathbf{1 0})$ & Crozet $(\boldsymbol{n = 4 9 )}$ & Kerguelen $(\boldsymbol{n}=\mathbf{2 7})$ & Marion $(\boldsymbol{n}=\mathbf{5 7})$ & TOTAL $(\mathbf{n = 1 4 3 )}$ \\
\hline With boats in seascape $\mathbf{( 1 0 0 k m )}$ & $9(90 \%)$ & $48(97.96 \%)$ & $27(100 \%)$ & $39(68.42 \%)$ & $\mathbf{1 2 3}(\mathbf{8 6 . 0 1 \% )}$ \\
\hline With boats encountered $\mathbf{( 3 0 k m )}$ & $8(80 \%)$ & $42(85.71 \%)$ & $23(85.19 \%)$ & $36(63.16 \%)$ & $\mathbf{1 0 9}(\mathbf{7 6 . 2 2 \% )}$ \\
\hline With boats attended $\mathbf{( 5 k m )}$ & $6(60 \%)$ & $36(73.47 \%)$ & $18(66.67 \%)$ & $27(47.37 \%)$ & $\mathbf{8 7}(\mathbf{6 0 . 8 4 \% )}$ \\
\hline
\end{tabular}

58 Table 3 - Correlations (with $\mathrm{p}$ value of Pearson test) between the number of AIS signals (total and for fishing boats only) per $5 \times 5^{\circ}$ grid cells and the time spent

59 by birds in same $5 \times 5^{\circ}$ grid cell (for a total time, for time with boats in seascape $(<100 \mathrm{~km})$, for time with boats in encounter $(<30 \mathrm{~km})$ and for time with boats in

60 attendance $(<5 \mathrm{~km}))$ for the active months of the different populations of albatrosses.

\begin{tabular}{|c|c|c|c|c|c|c|c|c|}
\hline \multirow[b]{2}{*}{ ANALYSES FOR $5 \times 5^{\circ}$ GRID } & \multicolumn{2}{|c|}{ Amsterdam ( $n=37$ cells) } & \multicolumn{2}{|c|}{ Crozet ( $n=63$ cells) } & \multicolumn{2}{|c|}{ Kerguelen ( $n=41$ cells) } & \multicolumn{2}{|c|}{ Marion ( $n=54$ cells) } \\
\hline & $\begin{array}{l}\text { Number of AIS } \\
\text { signals (April) }\end{array}$ & $\begin{array}{c}\text { Number of AIS } \\
\text { fishery signals } \\
\text { (April) }\end{array}$ & $\begin{array}{c}\text { Number of AIS signal } \\
\text { (January \& } \\
\text { February) }\end{array}$ & $\begin{array}{c}\text { Number of AIS } \\
\text { fishery signals } \\
\text { (January \& } \\
\text { February) } \\
\end{array}$ & $\begin{array}{l}\text { Number of AIS signals } \\
\text { (January \& February) }\end{array}$ & $\begin{array}{c}\text { Number of AIS } \\
\text { fishery signals } \\
\text { (January \& } \\
\text { February) } \\
\end{array}$ & $\begin{array}{c}\text { Number of AIS signals } \\
\text { (February \& March) }\end{array}$ & $\begin{array}{c}\text { Number of AIS } \\
\text { fishery signals } \\
\text { (February \& } \\
\text { March) }\end{array}$ \\
\hline Bird time spent in grid cell & $-0.113(p=0.52)$ & $-0.113(p=0.52)$ & $-0.094(p=0.48)$ & $-0.094(p=0.48)$ & $-0.039(p=0.81)$ & $-0.056(p=0.73)$ & $-0.012(p=0.94)$ & $-0.012(p=0.94)$ \\
\hline Bird time spent with boat at $100 \mathrm{~km}$ & $0.062(p=0.72)$ & $0.062(p=0.73)$ & $-0.021(p=0.87)$ & $-0.021(p=0.88)$ & $0.026(p=0.87)$ & $0.008(p=0.96)$ & $0.199(p=0.18)$ & $0.199(p=0.19)$ \\
\hline Bird time spent in encounter & $0.194(p=0.27)$ & $0.192(p=0.28)$ & $-0.029(p=0.83)$ & $-0.029(p=0.83)$ & $0.025(p=0.88)$ & $0.007(p=0.97)$ & $0.164(p=0.28)$ & $0.165(p=0.28)$ \\
\hline Bird time spent in attendance & $-0.050(p=0.78)$ & $-0.052(p=0.77)$ & $-0.038(p=0.78)$ & $-0.037(p=0.78)$ & $0.018(p=0.91)$ & $0.002(p=0.99)$ & $-0.014(p=0.93)$ & $-0.014(p=0.93)$ \\
\hline
\end{tabular}
61 


\section{Figures legends}

63 Figure 1 - Map of the South Indian Ocean with kernel utilization distribution 50\% (darker shade) and 90\% 64 (lighter shade) of birds for each site (triangles) $($ blue $=$ Amsterdam, green $=$ Crozet, red $=$ Kerguelen, orange $=$ 65 Marion); yellow dots represent encounter events and purple dots, attendance events; isobaths: -2000 m (shelf),

$660 \mathrm{~m}$ and $+2000 \mathrm{~m}$; light-green lines represent EEZ.

67 Figure 2 - Proxy of bycatch risk as (a) time spent per trip in attendance (within 5km) with fishing boats

68 (hours) and (b) Number of boat attended (within $5 \mathrm{~km}$ ) at any location; Mean and confidence interval (95\%)

69 of each site. Letters represent significant difference. 


\section{$571 \quad$ Figures}

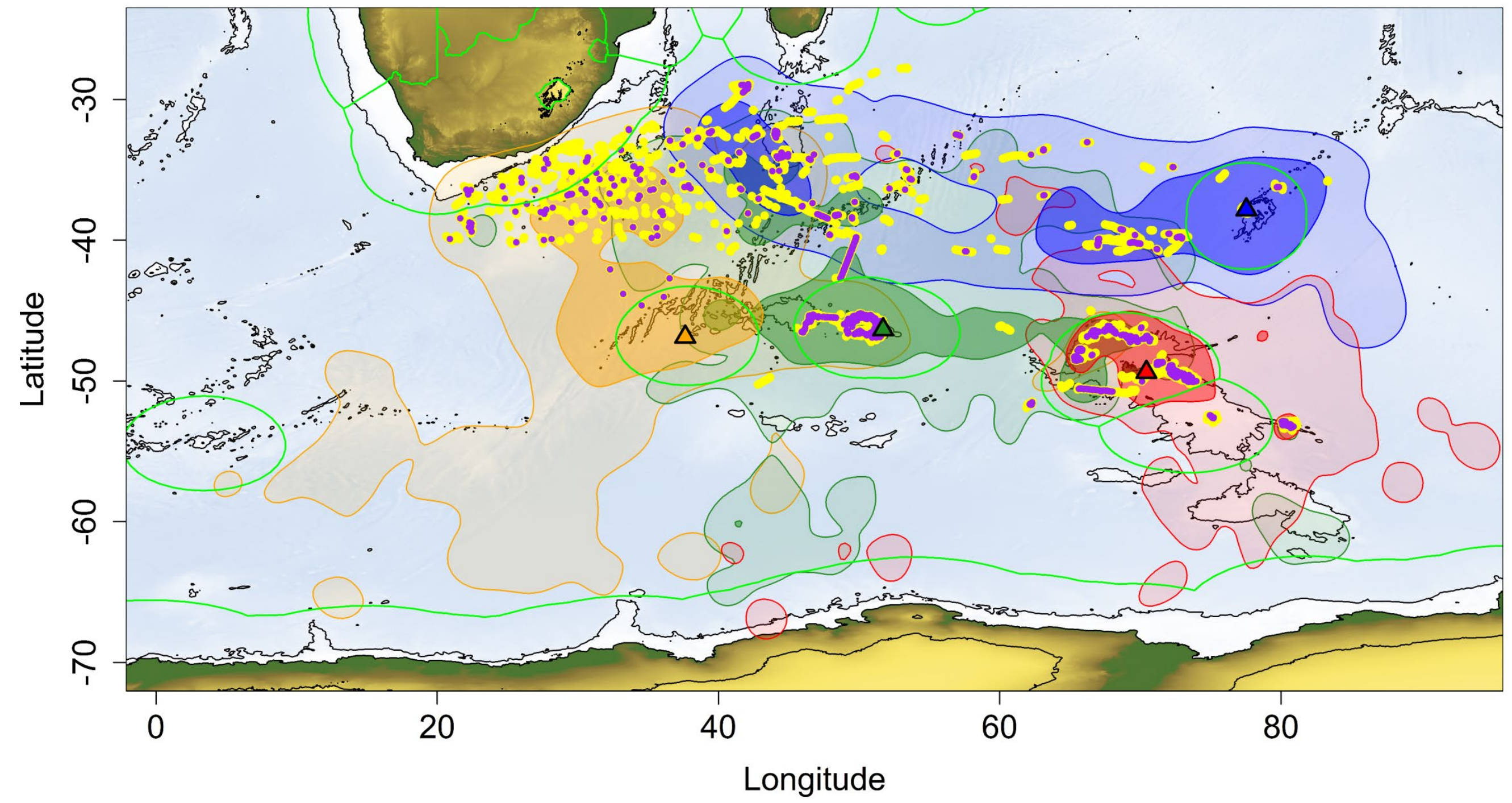

Figure 1 

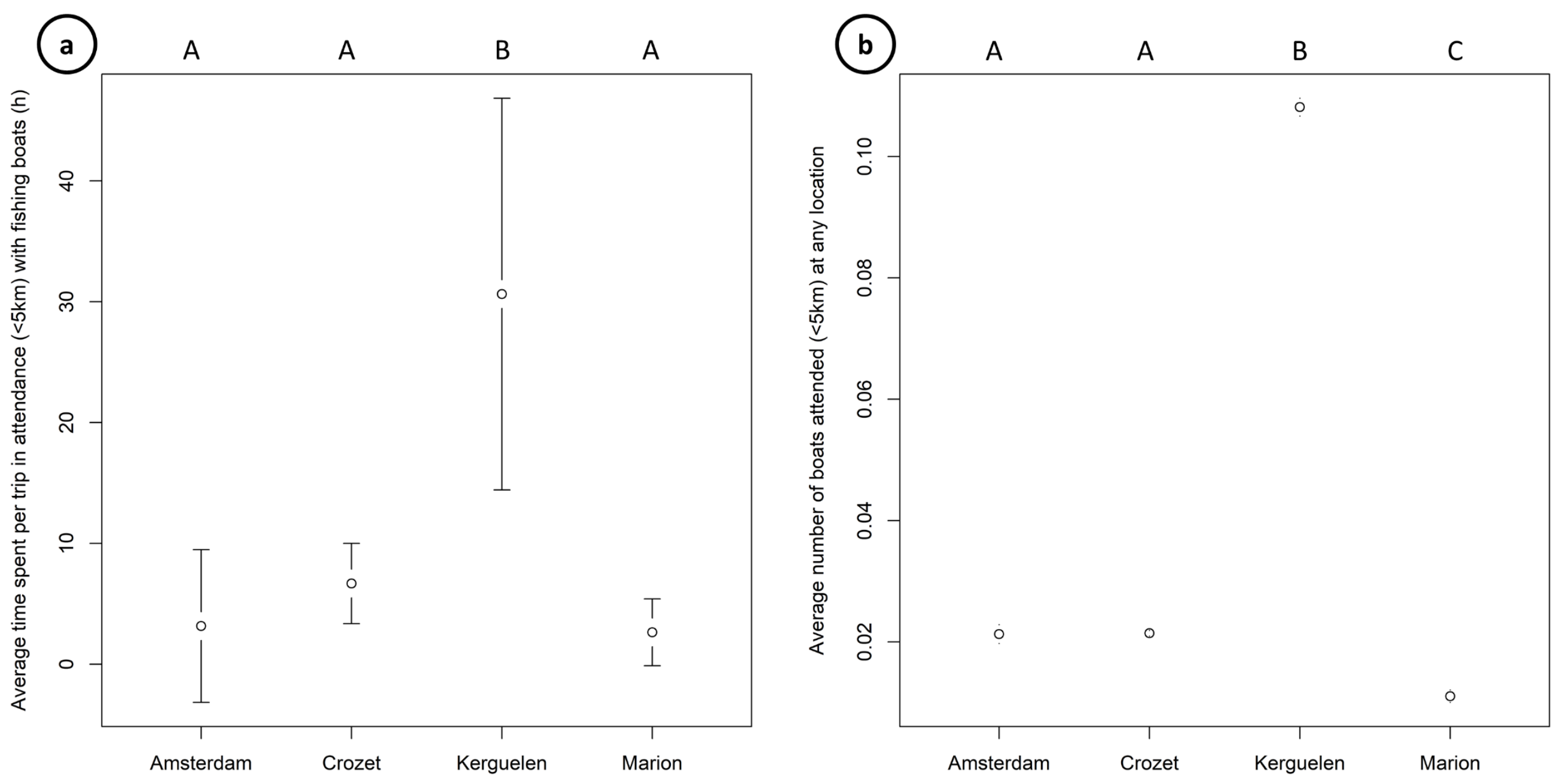

Figure 2 